various universities. Formerly, if a college was once affiliated, the university had practically no control of any kind over it, and though it might be known that a college was doing very inferior work, no effective. remedial action could be taken. Under the new Act the connection between the college and university is much closer and more effective than it has hitherto been. The conditions which a college must fulfil in order to receive and retain the privileges of affiliation are prescribed in some detail in the Act, and in order that the university may be satisfied as to the fulfilment of these conditions, systematic and periodic inspection of colleges by university inspectors is established, and this is coupled with the power of calling upon a college so visited to amend within a specified period any points over the wide range of requirements laid down by the Act. These inspections took place almost immediately after the passing of the University Act, and it is not too much to say that the condition of affairs disclosed showed abundantly the absolute necessity of the action taken to secure the passing of the new Act. Some colleges, indeed, have already had, or will have, to disappear if they do not rise to the required standard within a reasonable time. In other colleges where defects were found, due mainly, perhaps, to want of funds, arrangements are being made to remedy them, and these efforts are being supplemented by annual grants of money made by Government, which grants are administered by the universities.

Another direction in which radical changes are taking place under the new Act and its consequent regulations is in the matter of the residence of students. Formerly, in many cases, these conditions were deplorable, but gradually a much better state of things is being evolved, and here again the change is largely due to improvements made with money given for building hostels, \&c., by Government and by other donors.

That educational activity is increasing is also shown by the fact that at Allahabad in January of this year, the foundation stone of some important new university buildings was laid by Sir John Hewett, the Lieut.Governor of the United Provinces, who is also Chancellor of the Allahabad University, and by a demand which is now coming from Burma for a new university to be established there, in addition to the existing universities at Calcutta, Bombay, Madras, Allahabad, and the Punjab. As time goes on, indeed, there will probably be room, not only for the Burma University, but for others at such places as Nagpore, in the Central Provinces, and perhaps at Aligarh, which is now the centre of a large and exceedingly wellmanaged Mohammedan college.

Such are the main lines on which the improvements in university education in India are being conducted, but the effect of the new University Act does not end here, and it has also had an important bearing on the schools for secondary education. In most Indian universities, students usually can only go up for the matriculation examination if they have studied at a high school recognised by the university. The standard set by the university matriculation, therefore, largely influences the secondary schools. Formerly these standards were low, and in many ways unsatisfactory, while the schools which had been "recognised" were many of them most inferior in every way, specially in teaching and discipline, and they could not possibly impart sound education or develop character. Now the standards for the matriculation examination have been revised and generally raised, while also the conditions under which the secondary schools receive recognition have been formulated under the various university regulations, and unless a school is shown by inspection to be satisfactory in respect of constitution, management, and financial stability, premises and equipment, staff, instruction, and discipline, it cannot be recognised by the university, and hence cannot send up its pupils for examination. Inspection, therefore, has to be made of schools as well as of colleges, and this is rapidly raising the tone of the education given.

Hence the new University Act of 1904 is having a very marked and beneficial effect on all forms of college and high-school education, and India appears to be entering on a more prosperous era in the matter of higher education in all its branches than has hitherto been possible.

\section{THE NUTRITIVE VALUE OF BLACK BREAD.}

\section{DURING the last General Election much was} heard about the hard lot of the German workmen and peasants who are compelled to eat black bread, and much political capital was made of it. It may therefore be interesting to inquire how much of a hardship this is from the point of view of nutritiousness and also of tastiness. The so-called black bread is made of rye, and has the property of keeping moist for a much longer time than wheaten bread, although if kept too long it is apt to turn sour. It is quite a mistake to suppose that it is nasty; in New York, where wheaten bread is the staple article of diet, the German bakeries almost always also sell black bread, even in the best quarters of the town, and it is said that black bread is always to be found on the Emperor's table. So those who habitually buy white bread by no means entirely discard the use of black bread, though it does not appear to have found very much favour except with those of German extraction.

From the various analyses which have been published, the amount of nitrogenous material contained in the different cereals does not differ greatly nor constantly; but wheat has its nitrogenous matter partly in the form of gluten, a sticky material almost wanting in the other cereals. So far, then, as nitrogenous constituents are concerned, everything turns upon whether gluten is more nutritious than the other nitrogenous bodies. There is no reason to suppose that it is, but its adhesive properties are valuable in causing the dough, when permeated by carbonic acid gas, as a result of fermentation, to rise into a more porous, spongy mass. The nitrogenous material contained in the flour of all cereals when it is made into dough commences to decompose, and in this state acts as a ferment, breaking up a portion of the starch into dextrin and glucose, whilst some part of the starch undergoes a further fermentation into alcohol and carbonic acid gas. In this state the dough is called "leaven," and small portions of it are capable of setting up the same action in much larger masses of dough.

This is the old way of preparing bread, and is still employed in the making of black bread; in the making of finer breads it is not wholly discarded, although yeast is used for the initiation of the process. If this change goes far the bread loses in whiteness, and the addition of alum as an adulterant is made with the view of checking the fermentation. It is not generally known that the comparatively dark colour of whole-meal bread is not due to the particles of bran which it contains, but to the fermentative changes having gone further. This is due to the husk containing another nitrogenous body, which also acts as an active ferment. In fact, in white bread a large proportion of the starch remains unchanged.

But whole-meal bread is well known to have a 
higher nutritive value than white bread, probably partly on account of this conversion of the starch, which is a process indispensable to its digestion if it has not happened before it is eaten; and, of course, the whole-meal bread is richer in inorganic salts by the retention of the husk.

And it must not be supposed that rye bread is of necessity "black"; a bread that is lighter in colour than our brown bread can be made from rye flour, the depth of colour being dependent upon the treatment.

So far, then, there is not the smallest reason to suppose that black bread is inferior as a nutritive food to white bread, but rather the contrary.

Passing from the consideration of the nitrogenous (vegetable fibrin) constituents, rye contains as much or more starch and fatty matter as wheat. It contains more lime, about the same amount of magnesia, a good deal more silica, and slightly less phosphoric acid.

As the phosphates of lime and magnesia are needed for the calcification of bones and teeth, there is little to choose in this respect between a whole-meal wheaten bread and rye bread, both being superior to white bread. Formerly it was supposed that teeth of poor quality were actually deficient in lime salts, but this has been found not to be the case. Good teeth, whatever may be their chemical difference, and this has not been ascertained as yet, are unquestionably associated with good general nutrition in the growing person, and, of course, an adequate supply of lime and magnesia is essential to their formation. It should be added that the differences between samples of the same cereals are considerable, being apparently dependent upon the season, soil, and other conditions, so that in many cases the analyses show discrepant results.

But a consideration of the chemistry of the different breads gives no support to the idea that black bread is an inferior article of diet, and the German peasant is not to be pitied for having to use it. In texture it is moister, a little more sticky and doughy, does not get stale so soon, and it might not be wholly to the taste of those accustomed to wheaten bread, at all events at first. It is good food, nevertheless, and those accustomed to it often actually prefer it.

During the Crimean war the Russian prisoners in the hands of the French did not thrive, but after, on the advice of a Russian surgeon, they were given the black bread to which they were accustomed they did much better.

The political orator is not too particular about his facts so long as he thinks they will serve his turn, and the allegations made about black bread have been, to say the least, wanting in scientific accuracy, and so may be classed with much else that is heard from electioneering platforms as calculated, whether with intent or from ignorance, to convey a perfectly false impression.

\section{COMMANDER PEARY'S EXPEDITION TO THE NORTH POLE.}

NO geographical goal has been so long and 1 ardently desired as the North Pole. The glamour of the Dark Continent, the mystery of the South Polar lands, the lure of Potosi and Golconda, have never touched the popular imagination like the attraction of the North Pole. The whale and seal hunters of the seventeenth and eighteenth centuries developed the art of Arctic travel; while the Eskimo, the polar fauna, and the heroism of the knights of the frozen seas, kept an undue share of popular geographical interest "North where the bergs careen."
The commercial hopes that led to the search for the North-West Passage and the Franklin tragedy for a while made the Arctic Archipelago the centre of popular interest, but the North Pole, as a fixed spot, as definite as the winning post of a race, has kept its own as the goal most prized by sporting geographers.

It has at length been won, and the lecture by Commander Peary to the Royal Geographical Society, in the Albert Hall last night, told the story of the winning. The quest has been Commander Peary's one interest for twenty-four years; he has led four expeditions to reach the pole, after his remarkable exploration of the North Greenland ice-cap had given him the necessary experience, and had yielded him geographical results of perhaps greater scientific value than those of his last and most famous journey. He has carried through his work in an appropriately serious spirit. He has not regarded his quest as a mere matter of geographical athletics, but as a mission so important that he has been tempted to regard the Eskimo as placed by Providence in their inhospitable home on purpose to help him to his goal.

Commander Peary's lecture was a simple statement of the narrative of the expedition, and it gave no details as to the determination of the high latitudes, which geographers at this stage would have preferred to the short appendices giving the soundings and preliminary notes on the temperatures and tides. The expedition was apparently successful because a large force was able to start early in the season. Like Russia, according to Czar Nicholas, the pole has been protected by its ally, "General February"; but on this occasion the expedition began its journey from winter quarters in the middle of February. The party consisted of seven members, accompanied by seventeen Eskimos, I33 dogs, and nineteen sledges. With so large a staff a light advance party could be used to prepare the trail and successive divisions sent back from different stages, so that the final dash for the pole could be made by a party well equipped and comparatively fresh.

Commander Peary says that he and his comrades increased in fitness and training every day of the northern march. At a camp determined by Captain Bartlett as at $87^{\circ} 48^{\prime} \mathrm{N}$., that gallant officer and the last supporting party returned, leaving Peary, his negro servant Henson, and three Eskimo, with forty of the best dogs and five sledges. On April I Peary continued northward, hoping to reach the pole by five marches of twenty-five geographical miles each. At the end of the fifth march a temporary break in the clouds at "approximately local noon, Columbia meridian," enabled Peary to determine the position as $89^{\circ} 5 \tau^{\prime}$. A few hours later, with a light sledge carrying only instruments, drawn by a double team of dogs, he went on for another ten miles, and, as the sky cleared, he took observations, which showed that he had gone beyond the pole. After returning to camp he went eastward for eight miles, and both then and after his second return to camp he secured more observations, which confirmed his faith that he had reached and crossed the pole. Five miles from the pole he found a crack, and through a hole in it bored with a pickaxe he took a sounding of $\mathrm{r}_{5} \mathrm{Oo}$ fathoms, and found no bottom. The expedition returned south by forced marches, and it reached Cape Columbia in such fine trim that it crossed to Cape Hecla, and thence to the ship, in two marches of forty-five miles each.

The only definite scientific contributions announced are the soundings, which indicated a depth of only 3 Io fathoms at $85^{\circ} 23^{\prime}$; the depth had increased to more than 700 fathoms at ten miles further north, while at $87^{\circ}$ I $5^{\prime}$ the result was 1260 fathoms, with no NO. 2 I I 4, VOL. 83] 